\title{
KARAKTERISTIK PENYALAAN BRIKET LIMBAH SERBUK ARANG TEMPURUNG KELAPA DENGAN BAHAN PEMANTIK ABU KELAPA (COCODUST)
}

\section{IGNITION CHARACTERISTIC OF COCONUT SHELL CHARCOAL DUST BRIQUETTE WITH COCODUST AS FLINSTONE MATERIALS}

\author{
Petrus Patandung dan Doly Prima Silaban \\ Balai Riset dan Standardisasi Industri Manado \\ Jl. Diponegoro No. 21-23 Manado 95112 \\ e-mail: patandungp@yahoo.com
}

Diterima : 20-03-2017

Direvisi : 16-05-2017

Disetujui : 24-05-2017

\begin{abstract}
ABSTRAK
Tujuan penelitian ini untuk mengetahui karakteristik dan sifat-sifat penyalaan dari briket limbah serbuk arang tempurung kelapa dan cocodust sehingga produk briket yang diperoleh mudah dinyalakan dengan menggunakan bahan pemantik atau penyalaan awal. Metode penelitian ini disusun dalam percobaan pembuatan briket dan data dianalisa secara deskriptif. Percobaan dilakukan dengan pembuatan briket dengan menggunakan bahan perekat kanji $5 \%$ terhadap limbah arang, arang tempurung kelapa dan cocodust dengan kehalusan 10 mesh sebanyak 50 g,dengan perlakuan yang terdiri dari: $A 1=50 \mathrm{~g}$ limbah serbuk arang tempurung kelapa ditambah $50 \mathrm{~g}$ cocodust, $A 2=100$ $\mathrm{g}$ limbah serbuk arang tempurung kelapa ditambah $50 \mathrm{~g}$ cocodust, $\mathrm{A} 3=150 \mathrm{~g}$ limbah serbuk arang tempurung kelapa ditambah $50 \mathrm{~g}$ cocodust dan $\mathrm{A} 4=200 \mathrm{~g}$ limbah serbuk arang tempurung sebanyak $50 \mathrm{~g}$ kelapa ditambah $50 \mathrm{~g}$ cocodust, dilakukan pengulangan sebanyak 3 kali. Hasil analisa pembakaran arang briket dengan parameter: lama penyalaan sampai menjadi abu 141,18-146,14 menit; lama penyalaan awal sampai timbul api 0,17-0,30 menit dan asap yang ditimbulkan/asap yang hilang 18,18-25,18 menit. Untuk pendidihan air yang menggunakan arang briket serbuk limbah arang tempurung kelapa diperlukan waktu 30,15-35,16 menit dengan menggunakan arang briket sebanyak $100 \mathrm{~g}$. Hasil uji briket arang serbuk limbah arang tempurung kelapa antara lain kadar air 6,63-6,95 $\%$, abu 4,49-4,80\%; bagian yang hilang pada pemanasan suhu $950{ }^{\circ} \mathrm{C} 3,05-5,59 \%$ dan nilai kalori 4.608-5.221 kal/g. Hasil analisa menunjukkan bahwa perlakuan yang terbaik diperoleh pada perlakuan A2; A3 dan A4 karena semua parameter memenuhi syarat mutu, jika dibandingkan dengan SNI briket arang kayu 01-6235-2000.
\end{abstract}

Kata kunci: penyalaan, briket limbah arang tempurung, cocodust, pemantik

\section{ABSTRACT}

The purpose of this research is to know ignition characteristic of coconut shell charcoal dust briquette with cocodust as flintstone materials so that the briquette product obtained is easily ignited by using lighter material or start-up. The method of this research was experimental research of the making of briquettes and the data was analysed descriptively. The experiment was conducted by making briquettes using $5 \%$ starch adhesive material to charcoal coconut, charcoal waste and cocodust with fineness of 10 mesh with cocodust $50 \mathrm{~g}$, with treatment consisting of $A 1=50 \mathrm{~g}$ coconut shell charcoal waste plus $50 \mathrm{~g}$ cocodust; $A 2=100 \mathrm{~g}$ coconut shell charcoal waste plus $50 \mathrm{~g}$ cocodust; $A 3=150 \mathrm{~g}$ coconut shell charcoal waste plus $50 \mathrm{~g}$ cocodust and $A 4=200 \mathrm{~g}$ of shell charcoal waste of $50 \mathrm{~g}$ coconut plus $50 \mathrm{~g}$ cocodust, and it was repeated 3 times. The result of charcoal combustion analysis with the following parameters:duration of ignition up to Ash 141,18-146,14 minutes; Duration of initial ignition until fire arises 0,17-0,30 minutes and smoke generated/smoke loss 18,18-25,18 minutes. For boiling water using charcoal briquettes, charcoal waste briquettes waste coconut time 30.15-35.16 minutes using charcoal briquettes as much as $100 \mathrm{~g}$. Charcoal briquette charcoal waste 
coconut shell charcoal parameters: moisture content 6,63-6,95\%, ash 4,49-4,80 \%; The missing part at heating temperature $950^{\circ} \mathrm{C}$ from 3.05 to $5.59 \%$ and the calorific value of 4,608-5,221 cal/g. The result of the analysis showed that the best treatment was obtained at treatment A2; $A 3$ and $A 4$ because all parameters meet quality requirements when compared with SNI charcoal briquette SNI 01-6235-2000.

Keywords : ignition, charcoal waste charcoal briquettes, cocodust, lighter

\section{PENDAHULUAN}

Tanaman kelapa (cocos Nucifera LINN) merupakan salah satu komoditas hasil pertanian yang penting peranannya bagi kehidupan manusia, karena seluruh bagiannya dapat diolah sedemikian rupa menjadi berbagai produk industri. Pemanfaatan hasil tanaman kelapa di Sulawesi utara didominasi oleh daging buahnya sebagai protein nabati, airnya dibuat nata decoco, batangnya sebagai bahan bangunan dan lain sebagainya.

Berdasarkan data dan informasi dari Dinas Perkebunan Provinsi Sulawesi Utara, bahwa potensi perkebunan kelapa hibrida dan kelapa dalam cukup potensial yaitu seluas 279.489,10 $\mathrm{Ha}$ dengan produksi kopra 284.330,27 ton/tahun (Sulut dalam Angka, 2015). Disulawesi Utara sudah ada perusahaan yang mengolah arang tempurung menjadi komoditi ekspor baik dalam bentuk arang aktif maupun dalam pengolahan arang tempurung yang berbentuk butiranbutiran "chips " dan menghasilkan limbah serbuk arang yang belum diolah menjadi bahan industri dan hanya dibuang saja sehingga menimbulkan dampak lingkungan disekitar pabrik tempurung kelapa. Pengolahan arang tempurung kelapa menjadi berbagai ukuran yaitu 2-6 mesh menghasilkan limbah arang tempurung kelapa sekitar $30 \%$ yang sampai sekarang belum diolah menjadi bahan indutri, yang mana bahan tersebut masih mengandung nilai kalori yang cukup tinggi yaitu $5000-6000 \mathrm{kal} / \mathrm{g}$. Di samping turunan kelapa tersebut dari pengolahan kopra diperoleh juga sabut kelapa yang dapat menghasilkan serat dan cocodust yang belum diolah menjadi bahan industri dan hanya dibuang saja disekitar pengolahan sabut kelapa menjadi serat dan akhirnya menimbulkan dampak lingkungan.

Briket merupakan sumber energi cukup bagus untuk dikembangkan, karena bahan bakunya sangat berlimpah berasal dari kayu dan non kayu atau bahan-bahan limbah lainnya. Penggunaan briket salah satu kesulitan dalam penyalaan awal atau laju reaksi, karena briket tidak bisa menyala langsung bila tidak ada media penyulut/pemantik, yang biasa digunakan masih mengandalkan minyak tanah dan solar yang bersifat berbau dan berasap, dan harganya mahal dan susah didapat, sehingga penelitian ini digunakan bahan cocodust sebagai pemantik awal karena sifat karakteristiknya dan keunggulannya sangat mudah menyala atau terbakar dan menyebabkan berlangsung cepat.

Untuk menentukan mutu arang briket dapat digunakan standar mutu briket arang kayu dengan parameter: kadar air maksimum $8 \%$, bagian yang hilang pada pemanasan suhu $950{ }^{\circ} \mathrm{C}$ maksimum $15 \%$, abu maksimum $8 \%$ dan nilai kalori minimum $5000 \mathrm{kal} / \mathrm{g}$ sebagai pembanding (SNI 01-6235-2000). Briket adalah arang yang diolah lebih lanjut menjadi bentuk briket (penampilan dan kemasan yang lebih menarik) yang dapat digunakan untuk keperluan seharihari. Pembuatan briket dari limbah industri tempurung dan pengolahan sabut menjadi serat-serat dapat menghasilkan limbah yang dapat diproses menjadi arang selanjutnya di olah menjadi bentuk briket dengan menggunakan bahan perekat seperti tepung tapioka, dimana bahan baku tersebut digiling atau ditumbuk kemudian dicampur dengan bahan

perekat dengan menggunakan sistem hidrolik atau manual selanjutnya dikeringkan. Pembuatan arang briket dapat memberikan keuntungan antara lain 
dapat ditingkatkan kerapatannya sehingga volume menjadi kurang, bentuk dan ukurannya dapat disesuaikan dengan keperluan, tidak kotor, mudah diangkat, tidak memakan tempat pada waktu pengangkutan dan penyimpanan serta nilai kalorinya cukup tinggi (Ladeji, 2010). Arang serbuk sabut kelapa mengandung kadar air 3,50 \%, abu 4,40\%, bahan mudah menguap pada suhu $950{ }^{\circ} \mathrm{C} 12,56$ $\%$ dan karbon terikat 79,50 \% (Patandung et al, 1993). Peralatan dan mesin pembriketan dapat digolongkan sebagai berikut: Sistem mekanis tidak kontinyu, sistem hidrolik tidak kontinyu, Sistem ekstruksi kontinyu Sistem roll-press kontinyu (Apandi, 1995). Proses pembuatan briket dapat melalui beberapa tahap: penghancuran/penghalusanyaitu bahan baku digiling sampai halus kemudian diayak dengan menggunakan ayakan yang berukuran $2 \times 2 \mathrm{~mm}$ sehingga diperoleh bahan baku yang lolos ayakan tersebut dan digunakan sebagai bahan dasar pembuatan briket.

Bahan baku dicampur dengan perekat dan bahan-bahan lain agar dapat dicetak, bahan perekat yang digunakan adalah kanji dan tambahan perekat lainnya seperti bentonit dengan perbandingan tertentu kemudian dicampur sampai homogen lalu ditambahkan bahan pemantik lain seperti $\mathrm{KNO}_{3}$, dengan perbandingan sebagai berikut: 92,5 : 2,5: 2,0: Pencetakan adonan yang telah dicampur dicetak dengan menggunakan cetakan Screw press daya tekan $60-600 \mathrm{~kg} / \mathrm{cm}^{2}$, dengan demikian tekanan dapat diatur sehingga kepadatan briket dapat memenuhi standar mutu (Sudrajad, 2013). Penambahan bahan perekat adalah untuk memasukkan atau menarik air dan membentuk tektur yang padat atau menggabungkan antara dua atau lebih substrate yang direkat. Pemilihan dan penggunaan bahan perekat dilakukan dengan beberapa hal antara lain mempunyai daya serap yang baik terhadap air dan harganya relatife murah serta mudah didapat. Kekuatan perekat dipengaruhi oleh sifat briket, alat dan teknik perekatan yang digunakan, pematangan perekat akan terjadi dan menghasilkan keteguhan rekat yang baik disertai dengan tekanan yang cukup. Pemberian tekanan antara lain dimaksudkan untuk meratakan perekat dan untuk memasukkan perekat kedalam pori-pori. Ditinjau dari macam bahan perekat yang digunakan, produk yang dihasilkan dapat dibedahkan antara arang briket yang tidak atau kurang berasap dan banyak berasap. Pemakaian ter, pitch dan molase sebagai bahan perekat menghasilkan briket yang tinggi kekuatannya, tetapi memberikan asap jika dibakar (Hasanuddin, 2012). Oleh karena itu bahan perekat tersebut kurang cocok untuk membuat briket yang digunakan sebagai bahan bakar dalam rumah tangga. Bahan perekat dari zat pati, dekstrin dan tepung beras akan menghasilkan arang briket yang tidak berasap dan tahan lama, tetapi nilai kalorinya tidak terlalu tinggi (Surono, 2010).

Tujuan penelitian ini untuk mengetahui sifat-sifat penyalaan briket limbah arang tempurung kelapa dengan menggunakan cocodust sebagai bahan pemantik.

\section{METODE PENELITIAN Bahan dan Alat}

Bahan yang digunakan yaitu limbah arang tempurung kelapa, limbah cocodust dan kanji, sedangkan alat yang digunakan yaitu kompor, loyang plastik, pengaduk, alat pencampur dan alat cetak briket.

\section{Tempat dan Waktu Penelitian}

Penelitian dilaksanakan di Balai Riset dan Standardisasi Industri Manado Tahun 2015.

\section{Persiapan Bahan Baku}

Metode penelitian melalui 2 (dua) tahap penelitian yaitu limbah arang tempurung kelapa dari perusahaan arang tempurung kelapa yang berbentuk butiran-butiran diayak lewat ayakan 10 mesh kemudian dijadikan bahan baku untuk pembuatan briket. 


\section{Metode Penelitian}

Metode penelitian ini disusun dalam percobaan pembuatan briket dan data dianalisa secar deskriptif. Percobaan pembuatan briket dari limbah arang tempurung kelapa dan cocodust dapat dilihat pada Tabel 1.

Tabel 1. Percobaan Pembuatan Briket dari Limbah Serbuk Arang Tempurung Kelapa dengan Menggunakan Cocodust sebagai Pemantik.

\begin{tabular}{llll}
\hline Perlakuan & $\begin{array}{l}\text { Serbuk } \\
\text { arang } \\
\text { Temurung } \\
\text { kelapa }(\mathrm{g})\end{array}$ & $\begin{array}{l}\text { Cocodust } \\
(\mathrm{g})\end{array}$ & $\begin{array}{l}\text { Kanji } \\
(\%)\end{array}$ \\
\hline A1 & 50 & 50 & 5 \\
A2 & 100 & 50 & 5 \\
A3 & 200 & 50 & 5 \\
A4 & 300 & 50 & 5 \\
\hline
\end{tabular}

Penelitian diulang 3 (tiga) kali

\section{Pembuatan Briket}

Limbah arang tempurung kelapa ditimbang sesuai perlakuan dengan menggunakan bahan perekat kanji $5 \%$. Bahan perekat yang digunakan dilarutkan dengan air dingin terlebih dahulu kemudian ditambahkan air panas dan dimasak selama 10-15 menit sehingga membentuk pasta lalu bahan tersebut dicampur dengan limbah serbuk arang tempurung kelapa dan cocodust sampai homogen dan adonan dicetak dengan menggunakan pipa besi diameter $5 \mathrm{~cm}$ dan tinggi $4 \mathrm{~cm}$ kemudian produk briket dikeringkan disinar matahari selama 5-6 hari. Skema proses pembuatan briket dapat dilihat pada Gambar 1.

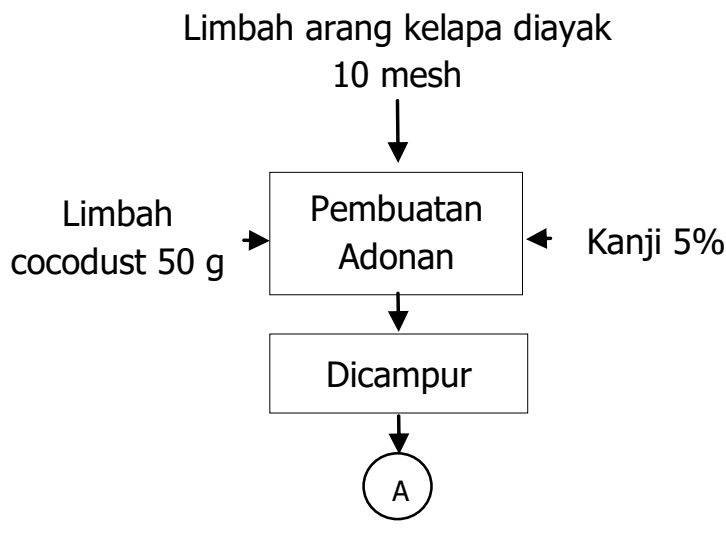

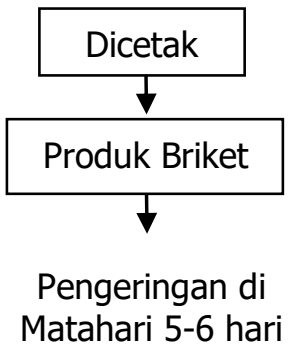

Gambar 1. Skema Proses Pembuatan Briket

\section{Parameter yang dianalisa}

Parameter yang dianalisa yaitu: lama penyalaan sampai menjadi abu, lama penyalaan awal sampai timbul api, asap yang ditimbulkan dan lama asap hilang, kadar air, abu, bagian yang hilang pada pemanasan suhu $950{ }^{\circ} \mathrm{C}$ dan nilai kalori(SNI Briket Arang Kayu 01-62352000).

\section{HASIL DAN PEMBAHASAN Pengujian Laboratorium}

Hasil pengujian laboratorium produk briket limbah arang tempurung kelapa dengan menggunakan cocodust sebagai bahan pemantik dan uji coba pembakaran briket dapat dilihat pada Gambar $2 ; 3$; 4; 5; 6; 7; 8 dan 9.

\section{Lama Penyalaan Sampai Menjadi Abu}

Hasil analisa uji coba pembakaran briket (Gambar 2) menunjukkan bahwa produk yang diperoleh dengan menggunakan arang limbah arang tempurung kelapa hasil pembakaran briket ternyata bahwa lama penyalaan sampai menjadi abu, hasil yang tertinggi diperoleh pada perlakuan A4 dengan menggunakan limbah arang tempurung kelapa $200 \mathrm{~g}$ dan cocodust $50 \mathrm{~g}$ yaitu sebesar 146,14 menit serta dengan yang terendah diperoleh pada perlakuan A1 dengan menggunakan limbah arang tempurung kelapa $50 \mathrm{~g}$ dan cocodust $50 \mathrm{~g}$ yaitu sebesar 141,18. 


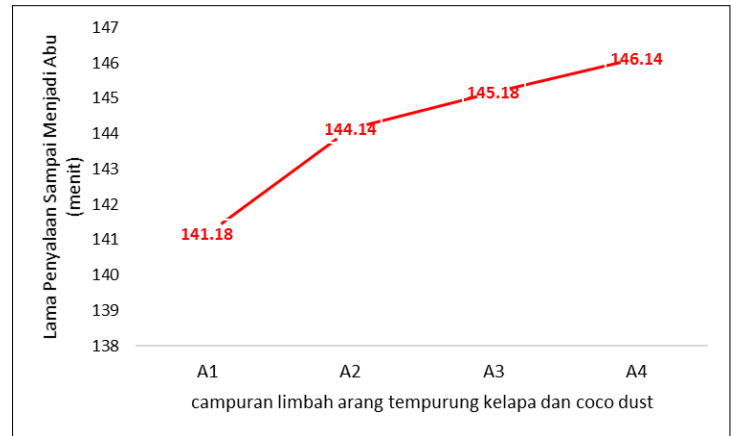

Gambar 2. Hubungan antara Campuran Limbah Arang Tempurung Kelapa dan Cocodust (g) Terhadap Lama Penyalaan sampai Menjadi Abu (menit)

Tinggi dan rendahnya lama penyalaan sampai menjadi abu disebabkan karena ukuran partikel dari serbuk limbah arang tempurung kelapa yang lebih halus sehingga kepadatan lebih rapat yang mengakibatkan rongga atau sirkulasi udara tidak merata kepermukaan briket dan juga oleh ukuran atau kehalusan dari cocodust (Jamilatun, 2008).

\section{Lama Penyalaan sampai Timbul Api}

Hasil analisa atau uji coba pembakaran briket (Gambar 3) dengan menggunakan limbah arang tempurung kelapa menunjukkan bahwa lama penyalaan sampai timbul api, hasil yang tertinggi diperoleh pada perlakuan A4 dengan menggunakan limbah serbuk arang tempurung kelapa $200 \mathrm{~g}$ dan cocodust $50 \mathrm{~g}$ yaitu sebesar 0,30 menit dan yang terendah diperoleh pada perlakuan A1 dengan menggunakan limbah arang serbuk tempurung kelapa 50 $\mathrm{g}$ dan cocodust $50 \mathrm{~g}$ yaitu sebesar 0,17 menit.

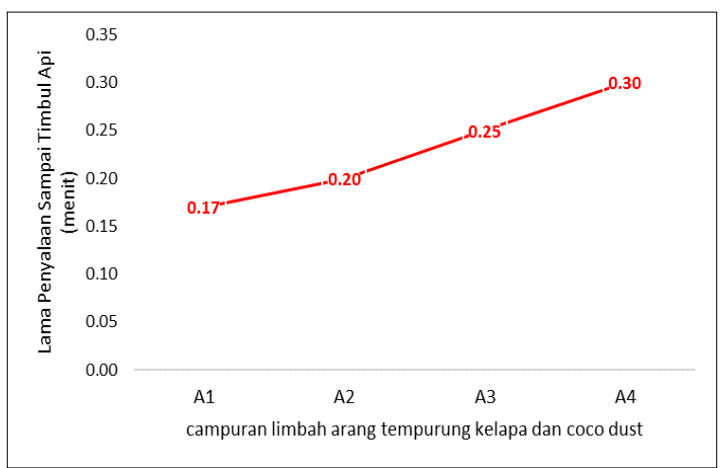

Gambar 3. Hubungan antara Campuran Limbah Arang Tempurung Kelapa dan Cocodust (g) Terhadap Lama Penyalaan sampai Timbul Api (menit)

Tinggi dan rendahnya hasil yang diperoleh disebabkan oleh kandungan air yang terdapat di dalam briket yaitu semakin tinggi kadar air semakin lama proses penyalaan dan semakin rendah kadar air semakin cepat proses penyalaan sampai timbul (Mongkau et al, 2011).

\section{Asap Yang Timbul/ Lama Ašmagi dan renda Hilang.}

Hasil analisa uji coba pembakaran briket yang menggunakan limbah arang limbah arang tempurung (Gambar 4) menunjukkan bahwa asap yang timbul berwarna putih dari semua perlakuan dan lama asap yang hilang yang tertinggi diperoleh pada perlakuan A4 dengan menggunakan limbah arang tempurung kelapa $200 \mathrm{~g}$ dan cocodust $50 \mathrm{~g}$ yaitu sebesar 25,18 menit dan yang terendah diperoleh pada perlakuan A1 dengan menggunakn $50 \mathrm{~g}$ limbah serbuk arang tempurung kelapa dan cocodust $50 \mathrm{~g}$ yaitu sebesar 18,18 menit.

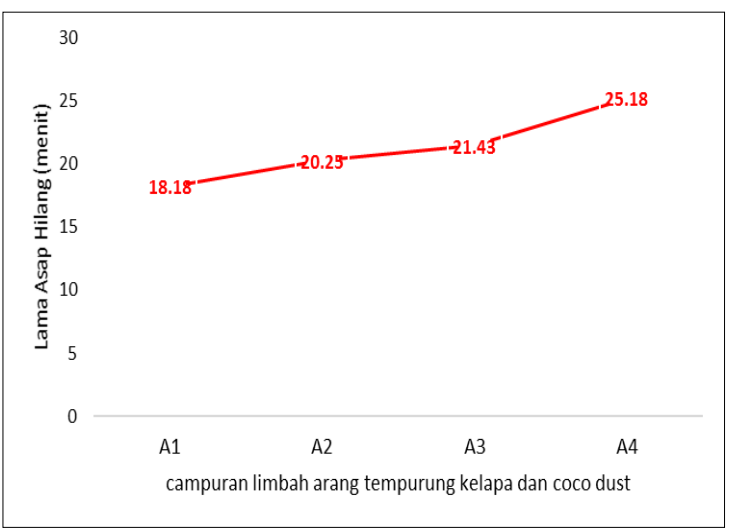

Gambar 4. Hubungan antara Campuran Limbah Arang Tempurung dan Cocodust $(\mathrm{g})$ Terhadap Lama Asap Hilang (menit)

Tinggi dan rendahnya hasil yang diperoleh lama asap hilang karena disebabkan oleh adanya komposisi biomassa dan kandungan air yang dikandung oleh briketyaitu semakin tinggi

54 Petrus Patandung dan Doly Prima Silaban

Karakteristik Penyalaan Briket Limbah Serbuk Arang

Tempurung Kelapa dengan Bahan Pemantik Abu Kelapa (Cocodust) 
kandungan air, semakin lama proses pembakaran berlangsung (Lubis, 2015).

\section{Lama Pendidihan Air}

Hasil uji coba pendidihan air (Gambar 5) dengan pembakaran briket 100 gram yang menggunakan air $500 \mathrm{ml}$ menunjukkan bahwa hasil yang tertinggi diperoleh pada perlakuan A4 dengan menggunakan arang briket limbah tempurung kelapa $200 \mathrm{~g}$ dan cocodust 50 g yaitu sebesar 35,16 menit dan hasil yang terendah diperoleh pada perlakuan A1 dengan menggunakan arang limbah arang tempurung kelapa $50 \mathrm{~g}$ dan cocodust $50 \mathrm{~g}$ yaitu sebesar 30,15 menit.

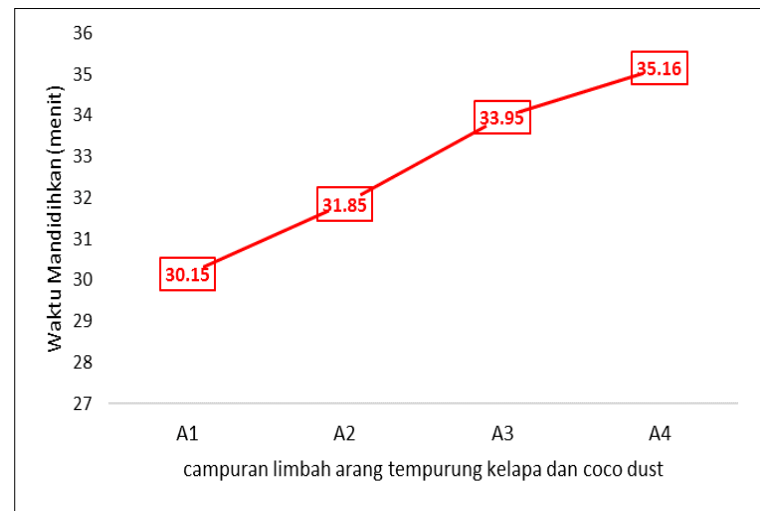

Gambar 5. Hubungan antara Campuran Serbuk Limbah Arang Tempurung Kelapa dan Cocodust (g) Terhadap Lama Waktu Mendidihkan Air (menit)

Hasil pendidihan air mengalami kenaikan dari limbah briket arang tempurung kelapa dipengaruhi oleh kadar air yaitu semakin tinggi kadar air proses pembakaran mengalami waktu yang lama dan sebaliknya briket yang mengandung kadar air rendah proses pembakaran mengalami waktu yang relatif singkat (Ridowati, 2015).

\section{Kadar Air}

Hasil analisia produk briket dengan menggunakan limbah arang tempurung kelapa (Gambar 6) menunjukkan bahwa hasil yang tertinggi diperoleh pada perlakuan A4 yaitu sebesar 6,95 \% dan yang terendah diperoleh pada perlakuan A1.

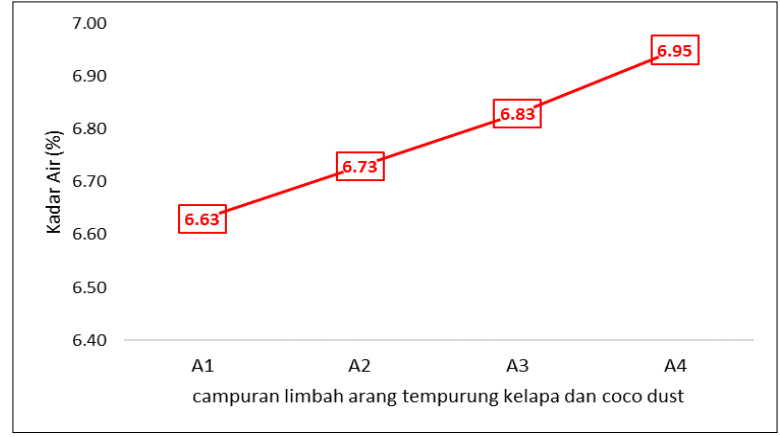

Gambar 6. Hubungan antara Campuran Serbuk Limbah Arang Tempurung Kelapa dan Cocodust (g) Terhadap Kadar air (\%)

Tinggi dan rendahnya hasil yang diperoleh disebabkan karena bahan baku yang cukup mengandung kadar air yang tinggi dan juga dipengaruhi oleh penambahan air pada proses pembuatan dan juga pengeringan, karena menggunakan pengeringan mata hari yang tidak menggunakan peralatan untuk mengukur suhu (Affandi, 2011).

\section{Kadar Abu}

Hasil analisa produk briket dengan menggunakan limbah briket arang tempurung kelapa (Gambar 7) menunjukan bahwa hasil yang tertinggi diperoleh pada perlakuan A3 dengan menggunakan limbah serbuk arang tempurung kelapa $150 \mathrm{~g}$ dan cocodust 50 $g$ yaitu sebesar $4,80 \%$ dan yang yang terendah diperoleh pada perlakuan A4 yang menggunakan serbuk limbah arang tempurung kelapa $200 \mathrm{~g}$ dan cocodust 50 g yaitu sebesar yaitu 4,49 \%. Jika dibandingkan dengan standar briket arang kayu SNI 01-6235- 2000 masih memenuhi syarat mutu yaitu maksimum $8 \%$.

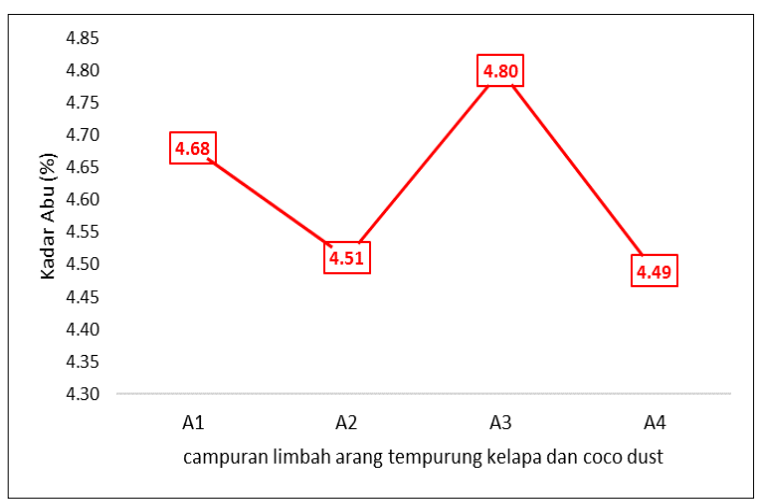


Gambar 7. Hubungan antara Campuran Serbuk Limbah Arang Tempurung Kelapa dan Cocodust (g) Terhadap Kadar Abu (\%)

Tinggi dan rendahnya hasil abu yang diperoleh disebabkan karena adanya penambahan serbuk limbah arang tempurung kelapa yang bervariasi sehinggasemakin tinggi abu yang dihasilkan, dan sebaliknya semakin rendah penambahan serbuk arang tempurung kelapa semakin rendah kadar abu (Christian, 2012).

\section{Bagian yang Hilang PadaPemanasan Suhu $950^{\circ} \mathrm{C}$.}

Hasil analisa briket arang (Gambar 8) dengan menggunakan serbuk limbah arang tempurung kelapa menunjukkan bahwa bagian yang hilang pada pemanasan suhu $950{ }^{\circ} \mathrm{C}$, hasil yang tertinggi diperoleh pada perlakuan A4 dengan menggunakan serbuk limbah arang tempurung kelapa $200 \mathrm{~g}$ dan cocodust $50 \mathrm{~g}$ yaitu sebesar 5,59 \% serta yang terendah diperoleh pada perlakuan A1 dengan menggunakan serbuk limbah arang tempurung kelapa $50 \mathrm{~g}$ dan cocodust $50 \mathrm{~g}$ yaitu sebesar 3,05 \%. Jika dibandingkan dengan standar briket arang kayu SNI 01-6235-2000 masih memenuhi syarat mutu.

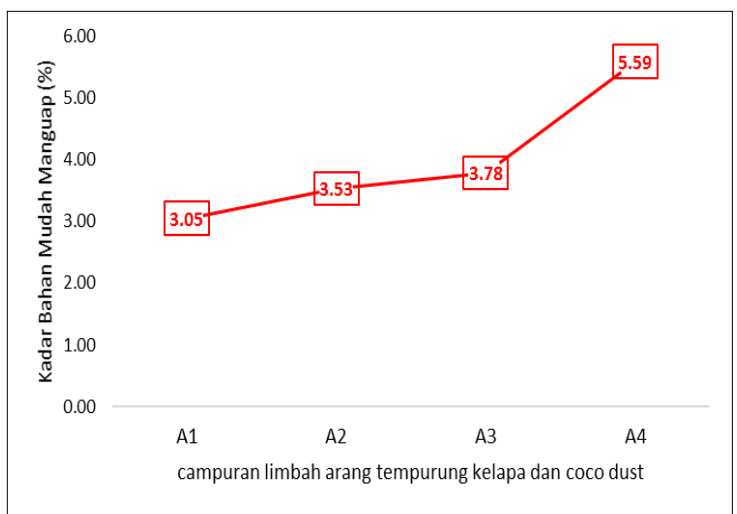

Gambar 8. Hubungan antara Campuran Serbuk Limbah Arang Tempurung Kelapa dan Cocodust (g) Terhadap Kadar Bahan Mudah Menguap pada Suhu $950{ }^{\circ} \mathrm{C}(\%)$

Tinggi dan rendahnya hasil yang diperoleh disebabkan karena adanya pengaruh dari kadar abu yang dihasilkan yaitu tingginya kadar abu menyebabkan bahan mudah menguap pada suhu 950 ${ }^{\circ} \mathrm{C}$ semakin tinggi, dan sebaliknya semakin rendah kadar abu yang diperoleh menyebabkan bahan mudah menguap pada suhu $950{ }^{\circ} \mathrm{C}$ semakin rendah (Ningrum, 2010).

\section{Nilai Kalori}

Hasil analisa produk briket dengan menggunakan briket limbah arang tempurung kelapa (Gambar 9) menunjukkan bahwa hasil yang tertinggi diperoleh pada perlakuan A4 dengan menggunakan serbuk limbah arang tempurung kelapa $200 \mathrm{~g}$ dan cocodust $50 \mathrm{~g}$ yaitu sebesar $5.221 \mathrm{kal} / \mathrm{g}$ dan yang terendah diperoleh pada perlakuan dengan menggunakan menggunakan $\mathrm{A} 1$ serbuk limbah arang tempurung kelapa $50 \mathrm{~g}$ dan cocodust $50 \mathrm{~g}$ yaitu sebesar $4.608 \mathrm{kal} / \mathrm{g}$. Tinggi dan rendahnya nilai kalori yang diperoleh dipengaruhi oleh variasi penggunaan variasi limbah arang tempurung kelapa yaitu semakin tinggi penggunaan limbah arang tempurung kelapa semakin tinggi nilai kalori, sebaliknya semakin rendah penggunaan limbah arang tempurung kelapa semakin rendah nilai kalori yang diperoleh (Mahmud, 2010).

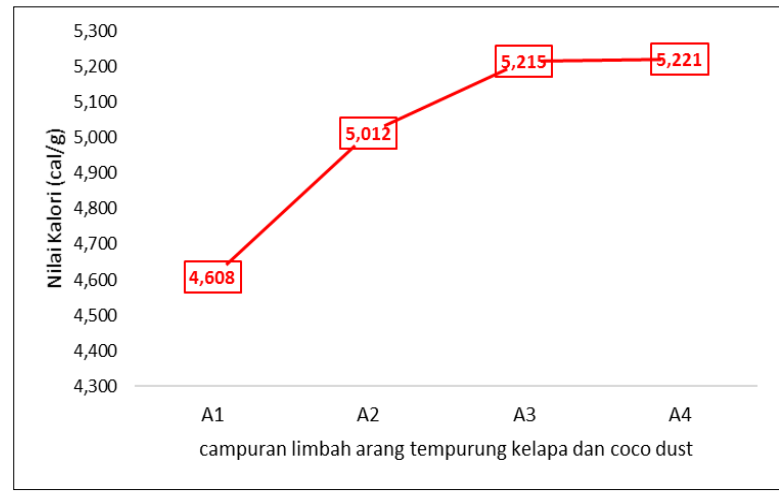

Gambar 9. Hubungan antara Campuran Serbuk Limbah Arang Tempurung Kelapa dan Cocodust (g) Terhadap Nilai Kalori (cal/g)

Jika dibandingkan dengan standar briket arang kayu SNI 01-6235- 2000 nilai kalori masih memenuhi Syarat mutu yaitu minimum $5000 \mathrm{kal} / \mathrm{g}$, kecuali perlakuan A1 
belum memenuhi syarat mutu yaitu 4.608 $\mathrm{kal} / \mathrm{g}$.

\section{KESIMPULAN}

Hasil penelitian menunjukkan bahwa cocodust dapat digunakan sebagai bahan pemantik atau bahan penyalaan awal dari pembakaran briket limbah arang tempurung kelapa. Hasil percobaan pembakaran arang briket limbah tempurung kelapa menunjukkan bahwa parameter lama penyalaan sampai menjadi abu 141,18-146,14 menit; lama penyalaan awal sampai timbul api 0,17-0,30 menit dan asap yang ditimbulkan/asap yang hilang 18,18-25,18 menit sedangkan pendidihan air menggunakan waktu 30,15-35,16 menit dengan menggunakan arang briket sebanyak $100 \mathrm{~g}$. Briket arang serbuk limbah tempurung kelapa parameter: kadar air 6,63-6,95 \%, abu 4,49-4,80\%; bagian yang hilang pada pemanasan suhu $950{ }^{\circ} \mathrm{C} 3,05-5,59 \%$ dan nilai kalori 4.608-5.221 kal/g. Hasil analisa menunjukkan bahwa perlakuan yang terbaik diperoleh pada perlakuan A2, A3 dan A4 karena semua parameter memenuhi syarat mutu, jika dibandingkan dengan SNI briket arang kayu 01-6235-2000.

\section{DAFTAR PUSTAKA}

Mongkau. A, Rahman. A, Bintaro. G, 2011, Nilai Kalori Briket Tongkol Jagung Dengan Berbagai Perbandingan Sekam Padi.

Christian. A, 2012, Pembuatan Arang Briket dari Limbah Blotong Pabrik Gula Dengan Proses Karbonisasi, Program Studi Teknik Kimia, Fakultas Teknologi Industri, Universitas Pembangunan Nasional " Veteran" Jawa Timur Surabaya.

Ridowati. A, 2015 Eko Bistik (Briket Sampah Plastik) dari Komposit Sampah Low Density Polyehthylene dan Kotoran Sapih Sebagai E n e r $\mathrm{g}$ i alternative
Ramah Lingkungan Berbasis

Renewable Resources, Jurusan Teknik Kimia, Universitas Semarang

Dewan Standar Nasional Indonesia, 2000, Syarat Mutu Arang Kayu, SNI 016235-2000, Kementrian Perindustrian

Hasanuddin, 2012. Pengaruh Perbandingan Komposisi Filler Dengan Perekat Pada Briket Ampas Tebu Terhadap NIlai Kalori, Jurusan Teknik Mesin, Universitas Hasanuddin

Lubis. J, 2015 Konsentrasi Perekat Tepung Tapioka Terhadap Nilai Kalori Batok Kelapa dan Tanah Humus Baturaden untuk Memurnikan Kadar Logam Krom (Cr), Jurnal Molekul, Vol. 5 No.2 : 66-74 USU Medan.

Ladeji, J. T. 2010 " Fuel characterization of Briquettes Produced from Corncob and Rice Husk resides " Pacific Journal of Science and Technology. 11 (1): 101-106.

Ningrum. N. S, 2010. Pembuatan Karbon Aktif (Bench Scale) dengan Bahan Baku Batu Bara, Departemen Energi dan Sumber Daya Mineral Republik Indonesia.

Affandi N, 2011. Karakteristik briket dari Arang Tongkol Jagung dengan Perekat Tetes Tebu dan Kanji Balai Riset dan Standardisasi Industri Pelembang.

Patandung. P, Pojoh. B Lohoo. F, Tambuwun. T. R, Saselah. 0, Dwihartanto, Wely. R \& Mamahani. F. G, 1993. Penelitian Pemanfaatan Serbuk sabut Kelapa Untuk Arang, Balai Penelitian dan Pengembangan Industri Manado.

Jamilatun. S. 2008 Sifat-sifat Penyalaan dan Pembakaran Briket Biomassa. Briket Batu Bara dan Arang Kayu, Progam Studi Teknik Kima, Universitas Dahlan Yogyakarta Jurnal Jurnal Teknologi Proses 2 (2): $65-72$.

Sudrajad. R, 2013, Crusher Process. Com Mesin Briket Ukuran Partikel Granular. 
Mahmud. N, 2010. Penentuan Nilai Kalori Bakar Berbagai Komposisi Bahan Bakar Minyak Nabati, Fakultas Sains dan Teknologi, Jurusan Kimia Universitas Malik Ibrahim, Malang.

Apandi. T. T, 1995. Rancang Bangun Mesin Pembriketan Batu Bara di Tegal, Jawa Tengah, Departemen Energi dan Sumber Daya Mineral RI.

Surono. U. B, 2010. Peningkatan Kualitas Pembakaran Biomassa Limbah Tongkol Jagung Sebagai Bahan Bakar Alternatif dengan Proses Karbonisasi dan Pembriketan, Jurnal Rekayasa Proses 4 (1): 13-18. 